\author{
Marzena Trajer ${ }^{1}$, Krystyna Krzyżanowska ${ }^{2}$ \\ ${ }^{1}$ Krajowy Ośrodek Wsparcia Rolnictwa, ${ }^{2}$ Szkoła Główna Gospodarstwa Wiejskiego \\ w Warszawie
}

\title{
Rolnictwo ekologiczne w Polsce i perspektywy jego rozwoju w kontekście PROW 2014-2020
}

\begin{abstract}
Streszczenie. Celem opracowania było określenie pozycji polskiego rolnictwa ekologicznego na tle rolnictwa ekologicznego w Unii Europejskiej (UE), regionalnego rozmieszczenia producentów ekologicznych w Polsce, a także rozpoznanie zakresu wsparcia finansowego w ramach Programu Rozwoju Obszarów Wiejskich w latach 2014-2020. W artykule wykorzystano dane wtórne i zastosowano metodę analizy porównawczej. Pod względem liczby gospodarstw ekologicznych Polska w 2015 r. zajęła szóstą pozycję w UE. Z analizy wynika, że najwięcej wniosków o dofinansowanie produkcji ekologicznej w ramach działania „Rolnictwo ekologiczne” zostało zrealizowanych w województwach z największą liczbą gospodarstw ekologicznych w Polsce, a więc zachodniopomorskim, warmińsko-mazurskim i podlaskim.
\end{abstract}

Słowa kluczowe: rolnictwo ekologiczne, Unia Europejska, PROW 2014-2020

\section{Wstęp}

Rolnictwo ekologiczne należy do systemu gospodarowania o zrównoważonej produkcji roślinnej i zwierzęcej w obrębie gospodarstwa. Produkcja prowadzona metodami ekologicznymi umożliwia wytworzenie produktu naturalnymi metodami produkcji, nienaruszającymi równowagi przyrodniczej ${ }^{1}$. Zasada ta dotyczy wszystkich rodzajów i etapów produkcji - zarówno produkcji roślinnej, chowu i hodowli zwierząt, produktów akwakultury, jak i przetwórstwa. Produkcja w ekologicznym gospodarstwie rolnym jest prowadzona zgodnie z zasadami zrównoważonego rozwoju, uaktywnia biologiczne procesy poprzez stosowanie naturalnych środków produkcji oraz zapewnia trwałą żyzność gleby, zdrowotność roślin i zwierząt. W szczególności produkcja ta polega na stosowaniu prawidłowego płodozmianu i innych naturalnych metod utrzymywania lub podwyższania biologicznej aktywności i żyzności gleby. Ważny jest również taki dobór gatunków i odmian roślin ras zwierząt, który uwzględniałby ich naturalną odporność na choroby ${ }^{2}$.

\footnotetext{
${ }^{1}$ S. Szarek: Regionalne zróżnicowanie rolnictwa ekologicznego w Polsce, Journal of Agribusiness and Rural Development 2015, 1(35), s. 125.

2 I. Molenda-Grysa: Przesłanki produkcji żywności ekologicznej w Polsce - typologia potencjałów, Roczniki Naukowe Ekonomii Rolnictwa i Rozwoju Obszarów Wiejskich 2016, t. 103, z. 3, s. 66.
}

${ }^{凶}$ krystyna_krzyzanowska@sggw.pl 
Warunki środowiskowe, strukturalne, społeczne i historyczne spowodowały, że polskie rolnictwo ma predyspozycje do stosowania ekologicznych metod produkcji żywności. W Polsce zużycie chemicznych środków produkcji było zawsze niższe niż w większości krajów europejskich, dlatego jakość ekologiczna przestrzeni produkcyjnej w rolnictwie, a także jej różnorodność biologiczna należą do najlepszych w Europie.

Bardzo często podkreśla się dwoistą naturę systemu rolnictwa ekologicznego. Jest to z jednej strony przede wszystkim system wpływający pozytywnie na środowisko naturalne, co z kolei przyczynia się do osiągania szeroko rozumianych korzyści rolnośrodowiskowych. Z drugiej jednak rolnictwo ekologiczne jest odpowiedzią na zmieniającą się strukturę popytu na rynku. Po wielkiej fascynacji świata produkcją żywności w warunkach przemysłowych konsument coraz częściej stwierdza, że tylko żywność powstała w warunkach jak najbardziej zbliżonych do naturalnych spełni jego oczekiwania ${ }^{3}$. Część konsumentów skłania się ku tym produktom, chce je kupować i zazwyczaj płaci za nie wyższą cenę niż za produkty, które nie zostały wytworzone takimi metodami. Zgodnie z tym podejściem system rolnictwa ekologicznego jest systemem rynkowym.

Działania na rzecz rozwoju rolnictwa ekologicznego stwarzają możliwości rozwiązywania problemów związanych z ochroną środowiska, dobrostanem zwierząt, a także rozwojem obszarów wiejskich przy jednoczesnym wytwarzaniu żywności wysokiej jakości. Produkcja prowadzona metodami ekologicznymi, wykorzystująca zasoby przyrodnicze jest najbardziej przyjazną dla środowiska i wpływa na znaczne ograniczenie zewnętrznych środków do produkcji. Rolnictwo ekologiczne spełnia jednak nie tylko rolę związaną z produkcją żywności, ale wpływa na utrzymanie i zwiększenie różnorodności biologicznej i walorów przyrodniczych rolniczej przestrzeni produkcyjnej. Dodatkowo rolnictwo ekologiczne poprzez swoją pracochłonność wpływa na zwiększenie zatrudnienia na obszarach wiejskich. Produkcja rolnicza metodami ekologicznymi ma coraz większe znaczenie, o czym świadczy wartość globalnego rynku produktów ekologicznych, która w 2014 roku przekroczyła 80 mld dolarów. Rolnictwo ekologiczne jest rozwijane w 172 krajach świata i zajmuje powierzchnię 43,7 $\mathrm{mln}$ ha użytków rolnych uprawianych przez 2,3 mln rolników4. Unia Europejska jest drugim (po USA i Kanadzie) rynkiem zbytu produktów ekologicznych na świecie. Globalne tendencje widoczne są również w Polsce. Konsumenci coraz bardziej świadomie wybierają produkty żywnościowe, kierując się nie tylko ceną czy wyglądem, ale zwracając uwagę na ich walory prozdrowotne. O wyborze produktów ekologicznych decydują również zalety związane z ochroną środowiska. Sprzyja to popularyzacji rolnictwa ekologicznego, które promuje zachowanie bioróżnorodności, a także ochronie środowiska i walorów krajobrazowych. Pozytywną tendencją jest wzrost zaufania polskich konsumentów do żywności ekologicznej, co stanowi dobrą prognozę na

\footnotetext{
${ }^{3}$ D. Komorowska: Efektywność ekologicznych gospodarstw sadowniczych w porównaniu do konwencjonalnych, Zeszyty Naukowe SGGW. Ekonomika i Organizacja Gospodarki Żywnościowej 2016, 115, s. 91. ${ }^{4}$ T. Miś, D. Zając: Problemy rozwoju rolnictwa ekologicznego w regionie o rozdrobnionej strukturze obszarowej, Zagadnienia Doradztwa Rolniczego 2017, 3, s. 21.
} 
przyszłość ${ }^{5}$. Program Europejskiego partnerstwa na rzecz wydajnego i zrównoważonego rolnictwa (ang. EIP-AGRI) ${ }^{6}$ potwierdza, że sektor rolnictwa ekologicznego jest w wielu aspektach liderem całego rolnictwa, ale potrzebuje on ciągłego rozwoju i innowacyjnych rozwiązań (Europejskie Partnerstwo Innowacji). Zdaniem autorów, w Polsce konieczny jest rozwój innowacyjnych rozwiązań, a także zaangażowanie producentów ekologicznych w Europejskie partnerstwo innowacyjne na rzecz wydajnego i zrównoważonego rolnictwa w celu poszukiwania możliwości innowacji w rolnictwie ekologicznym, w tym wzajemnej wymiany doświadczeń, rozwijania pomysłów, wiedzy i innowacyjnych przedsięwzięć. Ten rodzaj partnerstwa ma na celu mobilizować wiedzę naukową i praktyczną do postępu innowacji, przyspieszyć powstawanie nowych rozwiązań, co z kolei powinno pomóc w lepszym ukierunkowaniu badań naukowych mających na celu zaspokojenie potrzeb rynkowych w zakresie żywności ekologicznej.

\section{Cel i metodyka badań}

Celem opracowania jest przybliżenie pozycji polskiego rolnictwa ekologicznego na tle rolnictwa ekologicznego w UE, regionalnego rozmieszczenia producentów ekologicznych w Polsce, a także rozpoznanie zakresu wsparcia finansowego w ramach Programu Rozwoju Obszarów Wiejskich w latach 2014-2020. W artykule zastosowano metodę analizy porównawczej. Wykorzystano dane wtórne pochodzące z Głównego Inspektoratu Jakości Handlowej Artykułów Rolno-Spożywczych, Krajowego Ośrodka Wsparcia Rolnictwa, GUS i Eurostatu oraz literaturę przedmiotu. Wyniki badań przedstawiono w formie opisowej, tabelarycznej i graficznej.

\section{Rolnictwo ekologiczne w krajach Unii Europejskiej}

Rynek produktów ekologicznych w Unii Europejskiej rozwija się dynamicznie. Wartość sprzedaży detalicznej w całej UE w 2015 r. wyniosła 27,1 mld euro, co oznacza wzrost w stosunku do roku poprzedniego o $12,7 \%$. Unijny rynek produktów ekologicznych pod względem wartości sprzedaży detalicznej plasuje się na drugiej pozycji w świecie po rynku północnoamerykańskim (39 mld euro) ${ }^{7}$.

W Unii Europejskiej w 2015 r. powierzchnia użytków rolnych, na których prowadzono produkcję ekologiczną, wyniosła 11,1 mln ha. Wśród krajów o największej powierzchni upraw ekologicznych znalazły się: Hiszpania (2,0 mln ha), Włochy (1,5 mln ha), Francja (1,3 mln ha) oraz Niemcy (1,1 mln ha). Areał upraw ekologicznych w czterech

\footnotetext{
${ }^{5}$ Strefa Inspiracji Krajowego Ośrodka Wsparcia Rolnictwa, Moda na rolnictwo ekologiczne stała się faktem, www.kowr.gov.pl (dostęp: 20.11.2017).

${ }^{6}$ Europejskie partnerstwo innowacyjne na rzecz wydajnego i zrównoważonego rolnictwa (EIP-AGRI) stworzono w 2012 r. Ma ono przyczyniać się do realizacji strategii Unii Europejskiej „Europa 2020” na rzecz inteligentnego, trwałego wzrostu gospodarczego sprzyjającego włączeniu społecznemu. Intensyfikacja badań i innowacji jest jednym z pięciu głównych celów tej strategii, która promuje nowe interaktywne podejście do wspierania innowacji, http://ec.europa.eu/agriculture/research-innovation/eip-agriculture_pl (dostęp: 20.11.2017).

${ }^{7}$ FiBL\&IFOAM: The World of Organic Agriculture, Frick and Bonn 2017.
} 
wymienionych państwach stanowił ponad połowę powierzchni upraw ekologicznych w UE. Na kolejnych miejscach znajdowały się Polska (0,58 mln ha), Austria (0,55 mln ha) i Szwecja (0,52 mln ha). Szczegółowe dane dotyczące powierzchni upraw ekologicznych w Unii Europejskiej przedstawiono w tabeli 1.

Tabela 1. Powierzchnia ekologicznych użytków rolnych w UE w latach 2012-2015 (ha)

\begin{tabular}{|c|c|c|c|c|}
\hline \multirow{2}{*}{ Wyszczególnienie } & \multicolumn{4}{|c|}{ Lata } \\
\hline & 2012 & 2013 & 2014 & 2015 \\
\hline Austria & 533230 & 526689 & 525521 & 552141 \\
\hline Belgia & 59718 & 62471 & 66704 & 68818 \\
\hline Bułgaria & 39138 & 56287 & 47914 & 118552 \\
\hline Chorwacja & 31904 & 40660 & 50054 & 75883 \\
\hline Cypr & 3923 & 4315 & 3887 & 4699 \\
\hline Czechy & 468670 & 474231 & 472663 & 478033 \\
\hline Dania & 194706 & 169310 & 165773 & 166788 \\
\hline Estonia & 142065 & 151164 & 155560 & 155806 \\
\hline Finlandia & 197751 & 204810 & 210649 & 225235 \\
\hline Francja & 1030881 & 1060755 & 1118845 & 1322911 \\
\hline Grecja & 462618 & 383606 & 362826 & 407069 \\
\hline Hiszpania & 1756548 & 1610129 & 1710475 & 1968570 \\
\hline Holandia & 48038 & 48936 & 49159 & 49273 \\
\hline Irlandia & 52793 & 53812 & 51871 & 73037 \\
\hline Litwa & 156539 & 165885 & 164390 & 213579 \\
\hline Luksemburg & 4130 & 4447 & 4490 & 4216 \\
\hline Łotwa & 195658 & 185752 & 203443 & 231608 \\
\hline Malta & 37 & 7 & 34 & 30 \\
\hline Niemcy & 959832 & 1008926 & 1033807 & 1060291 \\
\hline Polska & 655499 & 669863 & 657902 & 580731 \\
\hline Portugalia & 200833 & 197295 & 212346 & 241375 \\
\hline Rumunia & 288261 & 286896 & 289252 & 245924 \\
\hline Słowacja & 164360 & 157848 & 180307 & 181882 \\
\hline Słowenia & 35101 & 38664 & 41237 & 42188 \\
\hline Szwecja & 477684 & 500996 & 501831 & 518983 \\
\hline Wlk. Brytania & 590011 & 558718 & 521475 & 495929 \\
\hline Węgry & 130607 & 130990 & 124841 & 129735 \\
\hline Włochy & 1167362 & 1317177 & 1387913 & 1492579 \\
\hline Ogółem & 10047897 & 10070639 & 10315169 & 11105865 \\
\hline
\end{tabular}

Źródło: opracowanie Krajowego Ośrodka Wsparcia Rolnictwa na podstawie danych Eurostat (dostęp: 10.02.2017). 
Wejście Polski do struktur UE dało krajowym producentom szansę na rozwój rolnictwa. Liczba gospodarstw ekologicznych w Polsce w latach 2005-2013 wzrosła z 7,2 tys. do 26,6 tys. W 2015 r. liczba gospodarstw ekologicznych wyniosła 22,3 tys. Pod względem liczby tych gospodarstw Polska w 2015 r. znajdowała się na szóstym miejscu w Unii Europejskiej za Włochami (52,6 tys.), Hiszpanią (34,6 tys.), Francją (28,8 tys.), Niemcami $(25,1$ tys.) oraz Austrią (23,1 tys.). Krajowi rolnicy stanowili 8,2\% unijnych ekologicznych producentów rolnych. Biorąc pod uwagę powierzchnię ekologicznych areałów, Polska w 2015 r. znajdowała się na piątym miejscu w UE (581 tys. ha) za Hiszpanią (1968 tys. ha), Włochami (1492 tys. ha), Francją (1322 tys. ha) oraz Niemcami (1060 tys. ha). Dane na ten temat przedstawiono na rysunku 1.

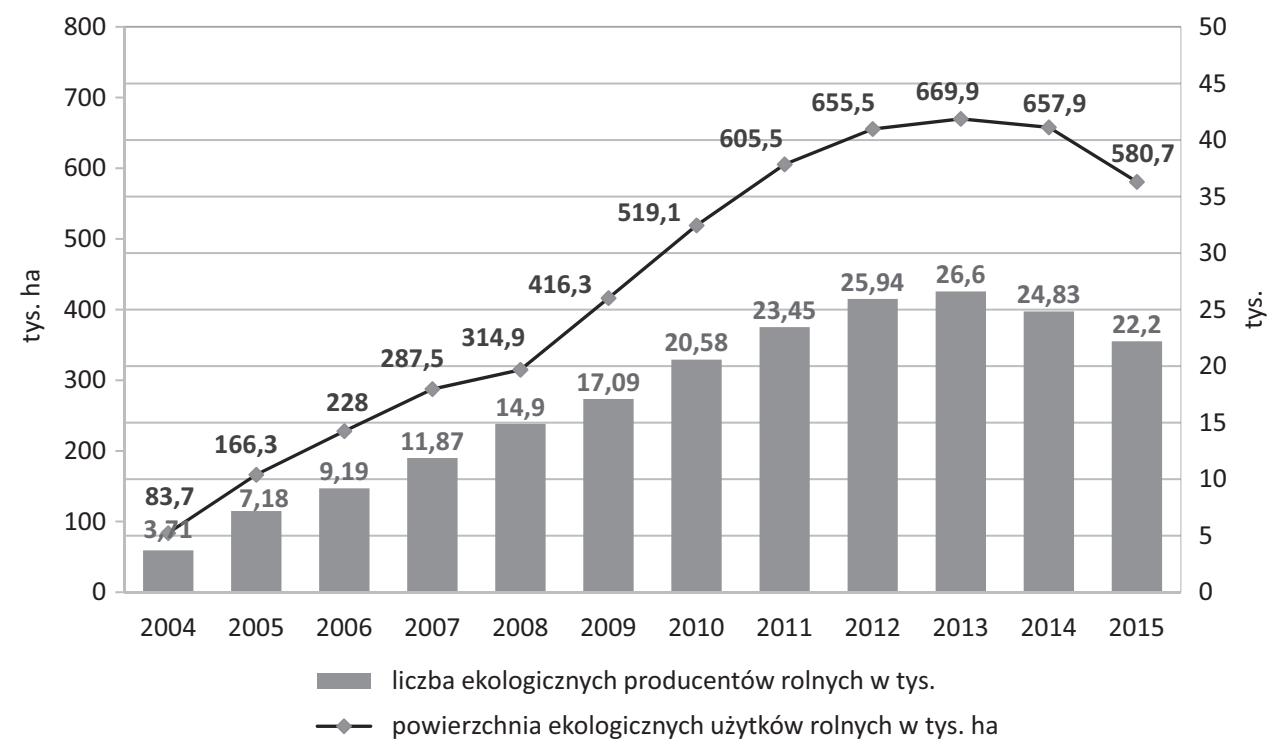

Rysunek 1. Liczba ekologicznych producentów rolnych i powierzchnia ekologicznych użytków rolnych w Polsce w latach 2004-2015

Źródło: opracowanie Krajowego Ośrodka Wsparcia Rolnictwa na podstawie danych IJHARS: Raporty o stanie rolnictwa ekologicznego w Polsce w latach 2005-2014 oraz Eurostat (dostęp: 10.02.2017).

W 2014 r. liczba gospodarstw ekologicznych spadła poniżej poziomu z lat 2012-2013. Wzrost nastąpił tylko w województwie podlaskim, a najmniejszy spadek w województwie warmińsko-mazurskim. W efekcie zmianie uległo również ich rozmieszczenie przestrzenne.

Najwięcej gospodarstw ekologicznych funkcjonowało na terenie województw: warmińsko-mazurskiego (4,2 tys.; 17\% ogółu gospodarstw ekologicznych w kraju), zachodniopomorskiego i podlaskiego (odpowiednio 3,5 i 3,4 tys.; po 14\%) oraz mazowieckiego (2,4 tys.; 10\%). Łącznie w tych czterech województwach funkcjonowało 55\% gospodarstw ekologicznych w Polsce. Najmniej gospodarstw ekologicznych było w województwach opolskim $(75 ; 0,3 \%)$ i śląskim (230; 0,9\%). 
Tabela 2. Liczba ekologicznych gospodarstw rolnych w Polsce w ujęciu przestrzennym w latach 2005-2014

\begin{tabular}{|l|c|c|c|c|c|c|c|c|c|c|}
\hline \multirow{2}{*}{ Województwo } & \multicolumn{9}{|c|}{ Lata } \\
\cline { 2 - 11 } & $\mathbf{2 0 0 5}$ & $\mathbf{2 0 0 6}$ & $\mathbf{2 0 0 7}$ & $\mathbf{2 0 0 8}$ & $\mathbf{2 0 0 9}$ & $\mathbf{2 0 1 0}$ & $\mathbf{2 0 1 1}$ & $\mathbf{2 0 1 2}$ & $\mathbf{2 0 1 3}$ & $\mathbf{2 0 1 4}$ \\
\hline Dolnośląskie & 395 & 481 & 652 & $\mathbf{8 7 9}$ & 1021 & 1227 & 1322 & 1312 & 1189 & 1046 \\
\hline $\begin{array}{l}\text { Kujawsko- } \\
\text {-pomorskie }\end{array}$ & 145 & 173 & 217 & 258 & 279 & 327 & 371 & 390 & 415 & 401 \\
\hline Lubelskie & 774 & 1072 & 1402 & 1566 & 1710 & 1962 & 2065 & 2174 & 2129 & 1975 \\
\hline Lubuskie & 188 & 256 & 361 & 480 & 579 & 833 & 1081 & 1356 & 1422 & 1370 \\
\hline tódzkie & 171 & 218 & 261 & 314 & 366 & 420 & 478 & 518 & 528 & 508 \\
\hline Małopolskie & 1187 & 1363 & 1627 & 2100 & 2197 & 2156 & 2138 & 2103 & 1838 & 1378 \\
\hline Mazowieckie & 852 & 1028 & 1215 & 1481 & 1673 & 1935 & 2140 & 2373 & 2609 & 2374 \\
\hline Opolskie & 38 & 46 & 53 & 62 & 63 & 79 & 86 & 90 & 88 & 75 \\
\hline Podkarpackie & 855 & 1164 & 1577 & 1892 & 2014 & 2091 & 2045 & 1940 & 1750 & 1475 \\
\hline Podlaskie & 482 & 628 & 847 & 1160 & 1528 & 2033 & 2440 & 2924 & 3407 & 3432 \\
\hline Pomorskie & 180 & 222 & 273 & 392 & 494 & 648 & 763 & 894 & 893 & 847 \\
\hline Śląskie & 92 & 116 & 143 & 176 & 199 & 228 & 238 & 236 & 242 & 230 \\
\hline Świętokrzyskie & 785 & 892 & 995 & 1165 & 1170 & 1243 & 1296 & 1288 & 1207 & 992 \\
\hline $\begin{array}{l}\text { Warmińsko- } \\
\text {-mazurskie }\end{array}$ & 432 & 586 & 773 & 1059 & 1514 & 2279 & 3033 & 3793 & 4235 & 4234 \\
\hline Wielkopolskie & 202 & 264 & 415 & 516 & 588 & 748 & 888 & 974 & 1006 & 966 \\
\hline $\begin{array}{l}\text { Zachodnio- } \\
\text { pomorskie }\end{array}$ & 404 & 678 & 1059 & 1396 & 1696 & 2373 & 3065 & 3579 & 3640 & 3526 \\
\hline Ogółem & 7182 & 9187 & 11870 & 14896 & 17091 & 20582 & 23449 & 25944 & 26598 & 24829 \\
\hline
\end{tabular}

Źródło: opracowanie Krajowego Ośrodka Wsparcia Rolnictwa na podstawie danych IJHARS: Raporty o stanie rolnictwa ekologicznego w Polsce w latach 2005-2014.

W Polsce w latach 2014-2015 areał ekologicznych użytków rolnych uległ zmniejszeniu z 670 tys. ha w 2013 r. do 581 tys. ha w 2015 r. Udział ekologicznych użytków rolnych, w stosunku do użytków rolnych ogółem, w skali całego kraju wynosił średnio 3,1\% w 2012 r., 3,8\% w 2014 r. i 3,5\% w 2015 r. W 2015 r. największy udział gruntów wykorzystywanych do produkcji ekologicznej w areale użytków rolnych ogółem odnotowano w województwie zachodniopomorskim (12\% użytków rolnych ogółem), lubuskim (10\%) oraz warmińsko-mazurskim (9\%), natomiast najmniejszy w województwie opolskim $(0,45 \%)$.

Według danych z 2014 r. w Polsce 80,7\% gospodarstw ekologicznych prowadziło wyłącznie produkcję roślinną, a 19,3\% zarówno produkcję roślinną, jak i zwierzęcą. W 39,4\% gospodarstw łączono produkcję ekologiczną z produkcją konwencjonalną ${ }^{8}$.

\footnotetext{
${ }^{8}$ Raport o stanie rolnictwa ekologicznego w Polsce w latach 2013-2014, IJHARS, Warszawa 2015 oraz Eurostat.
} 


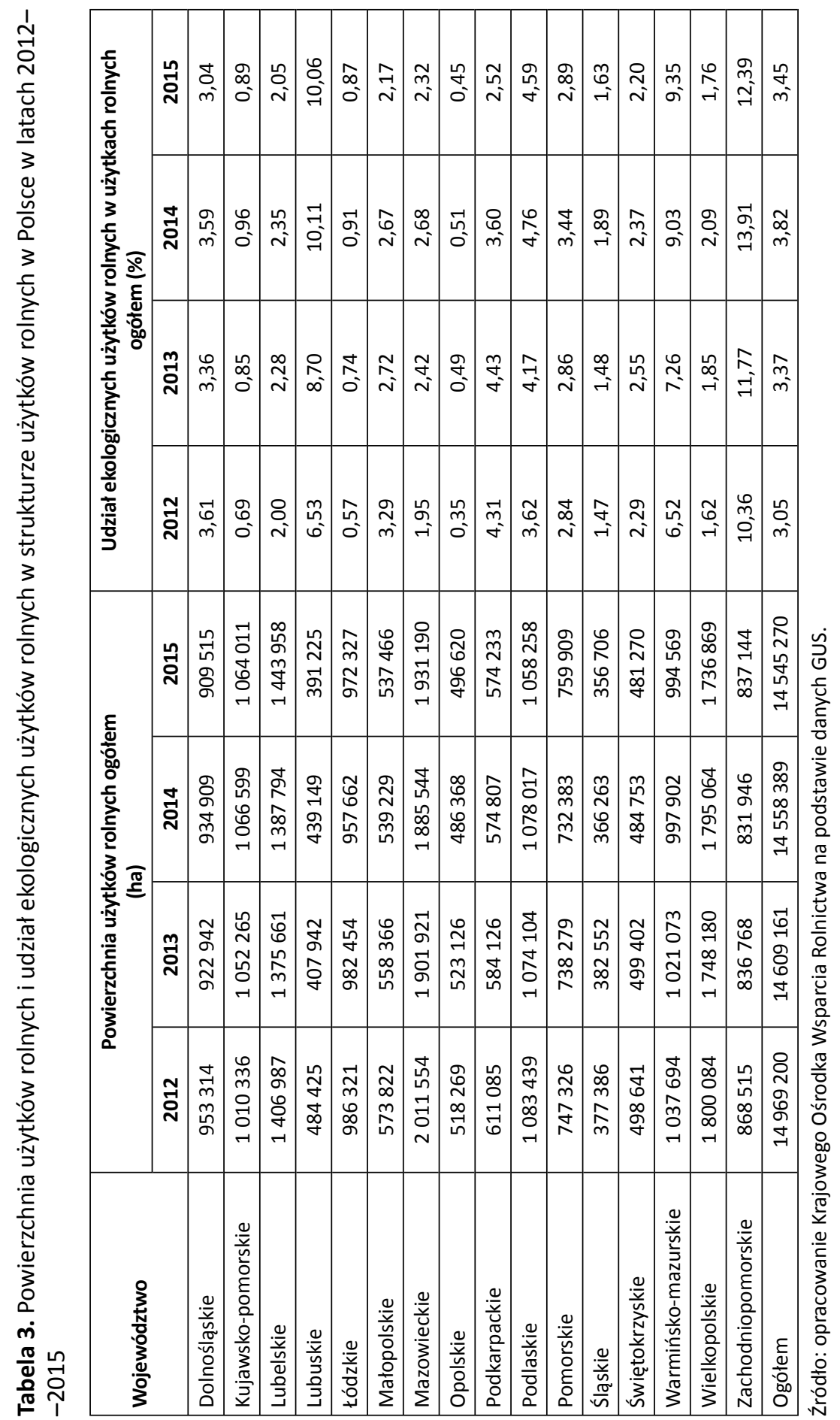




\section{Możliwości wsparcia finansowego rolnictwa ekologicznego z Programu Rozwoju Obszarów Wiejskich na lata 2014-2020}

Program Rozwoju Obszarów Wiejskich na lata 2014-2020 (PROW 2014-2020) jest najważniejszym narzędziem wsparcia rozwoju obszarów wiejskich. Dzięki PROW 2014-2020 realizuje się "Strategię zrównoważonego rozwoju wsi, rolnictwa i rybactwa”, w tym cel ogólny i te cele szczegółowe strategii, które odpowiadają misji i celom wspólnej polityki rolnej oraz unijnym priorytetom rozwoju obszarów wiejskich. Wsparcie w ramach PROW 2014-2020 jest również najważniejszym narzędziem realizacji „Ramowego Planu Działań dla Żywności i Rolnictwa Ekologicznego w Polsce na lata 2014-2020”.

W ramach PROW 2014-2020 producenci ekologiczni mogą wnioskować o wsparcie na zasadach ogólnych w ramach wszystkich działań. Należy jednak zaznaczyć, iż są również specjalne działania dla producentów ekologicznych oraz działania zakładające preferencje dla produkcji ekologicznej.

W PROW 2014-2020 producenci ekologiczni mogą otrzymywać wsparcie do powierzchni upraw prowadzonych zgodnie z przepisami o rolnictwie ekologicznym w ramach działania „Rolnictwo ekologiczne”. Zakres tego działania obejmuje wspieranie dobrowolnych zobowiązań rolników, którzy podejmą się utrzymać lub przejść na praktyki i metody rolnictwa ekologicznego określone w rozporządzeniu Rady (WE) nr 834/2007. Wszystkie uprawy deklarowane do wsparcia finansowego w ramach działania „Rolnictwo ekologiczne” podlegają tak jak dotychczas kontroli upoważnionych jednostek certyfikujących. Beneficjentem może być rolnik aktywny zawodowo, mający gospodarstwo rolne położone na terytorium Rzeczypospolitej Polskiej, o powierzchni użytków rolnych nie mniejszej niż 1 ha, który zobowiąże się do realizacji rolnictwa ekologicznego przez okres 5 lat oraz do przestrzegania wymagań wynikających z poszczególnych pakietów/ wariantów ekologicznych. Rolnik, który zdecyduje się na przestawienie gospodarstwa na system ekologiczny, może otrzymać w ramach nowego PROW 2014-2020 pomoc finansową w wysokości od 428 zł do 1882 zł/ha ${ }^{9}$. Przestrzenne zróżnicowanie dofinansowania rolnictwa ekologicznego przedstawiono w tabeli 4.

Jak wynika z analizy przeprowadzonej do 30 września 2017 r., najwięcej wniosków o dofinansowanie produkcji ekologicznej zostało przyjętych i zrealizowanych w województwach warmińsko-mazurskim, zachodniopomorskim i podlaskim, co było skorelowane z największą liczbą gospodarstw ekologicznych występujących na tych terenach.

W ramach PROW 2014-2020 producenci ekologiczni mogą również wnioskować o wsparcie na zasadach ogólnych w ramach wszystkich działań. Jedną z możliwości jest działanie „Systemy jakości produktów rolnych i środków spożywczych”, w ramach którego są realizowane dwa poddziałania: „Wsparcie dla nowych uczestników systemów jakości” i „Wsparcie na przeprowadzenie działań informacyjnych i promocyjnych”. Poddziałanie „Wsparcie dla nowych uczestników systemów jakości” polega na refundacji kosztów stałych wynikających z udziału rolnika w systemie jakości, w tym rolnictwa ekologicznego, przez maksymalny okres trzech lat. Wsparcie udzielane jest jako roczna

\footnotetext{
${ }^{9}$ T. Miś, D. Zając: op.cit., s. 21.
} 
Tabela 4. Zrealizowane płatności z PROW 2007-2013 i 2014-2020 w ramach działania „Rolnictwo ekologiczne" (stan na 30.09.2017)

\begin{tabular}{|c|c|c|c|c|c|c|}
\hline \multirow[b]{2}{*}{ Województwo } & \multicolumn{2}{|c|}{ Zrealizowane płatności } & \multicolumn{2}{|c|}{$\begin{array}{l}\text { Zrealizowane płatności } \\
\text { z PROW 2007-2013 }\end{array}$} & \multicolumn{2}{|c|}{$\begin{array}{l}\text { Zrealizowane płatności } \\
\text { z PROW 2014-2020 }\end{array}$} \\
\hline & $\begin{array}{c}\text { liczba } \\
\text { beneficjen- } \\
\text { tów }\end{array}$ & $\begin{array}{l}\text { kwota } \\
\text { ogółem } \\
\text { (tys. zł) }\end{array}$ & $\begin{array}{c}\text { liczba } \\
\text { beneficjen- } \\
\text { tów }\end{array}$ & $\begin{array}{l}\text { kwota } \\
\text { ogółem } \\
\text { (tys. zł) }\end{array}$ & $\begin{array}{c}\text { liczba } \\
\text { beneficjen- } \\
\text { tów }\end{array}$ & $\begin{array}{l}\text { kwota } \\
\text { ogółem } \\
\text { (tys. zł) }\end{array}$ \\
\hline Dolnośląskie & 861 & 28380,9 & 603 & 16383,6 & 313 & 11997,3 \\
\hline $\begin{array}{l}\text { Kujawsko- } \\
\text {-pomorskie }\end{array}$ & 366 & 11554,3 & 268 & 7757,9 & 131 & 3796,4 \\
\hline Lubelskie & 1975 & 38047,4 & 1335 & 23213,7 & 771 & 14833,7 \\
\hline Lubuskie & 1306 & 58847,7 & 1041 & 41825,1 & 342 & 17022,7 \\
\hline Łódzkie & 485 & 12318,7 & 331 & 7530,9 & 195 & 4787,8 \\
\hline Małopolskie & 1121 & 13144,9 & 864 & 9407,7 & 311 & 3737,2 \\
\hline Mazowieckie & 2234 & 56270,1 & 1618 & 35306,1 & 762 & 20964,0 \\
\hline Opolskie & 73 & 3802,7 & 48 & 1897,5 & 32 & 1905,1 \\
\hline Podkarpackie & 1239 & 15806,5 & 901 & 10487,8 & 418 & 5318,7 \\
\hline Podlaskie & 3493 & 69017,4 & 2684 & 48620,9 & 1026 & 20396,5 \\
\hline Pomorskie & 779 & 29 198,2 & 586 & 18743,3 & 240 & 10454,9 \\
\hline Śląskie & 183 & 5893,7 & 143 & 4527,4 & 54 & 1366,3 \\
\hline Świętokrzyskie & 882 & 12 170,1 & 679 & 8937,3 & 251 & 3232,8 \\
\hline $\begin{array}{l}\text { Warmińsko- } \\
\text {-mazurskie }\end{array}$ & 4383 & 135308,9 & 3344 & 90942,3 & 1323 & 44366,6 \\
\hline Wielkopolskie & 802 & 34617,2 & 624 & 23957,2 & 234 & 10660,0 \\
\hline $\begin{array}{l}\text { Zachodnio- } \\
\text { pomorskie }\end{array}$ & 3166 & 135901,7 & 2619 & 97 106,9 & 797 & 38794,8 \\
\hline Razem & 23325 & 660280,4 & 17673 & 446645,6 & 7196 & 213634,8 \\
\hline
\end{tabular}

Źródło: opracowanie własne na podstawie danych Agencji Restrukturyzacji i Modernizacji Rolnictwa.

płatność motywująca, której poziom zostanie ustalony na podstawie kosztów faktycznie wynikających z udziału w systemie jakości. Koszty podlegające refundacji obejmują koszty przystąpienia do systemu jakości i roczne koszty uczestnictwa w tym systemie. Do kosztów kwalifikowalnych mogą być zaliczone wydatki poniesione na niezbędne kontrole procesu produkcji z wymaganiami danego systemu. $W$ ramach drugiego poddziałania „Wsparcie na przeprowadzenie działań informacyjnych i promocyjnych” wspierane są działania o charakterze informacyjno-promocyjnym, mające na celu popularyzację i wspomaganie identyfikacji m.in. produktów ekologicznych, a tym samym zwiększenie popytu na te produkty na rynku wewnętrznym. W ramach tego działania o wsparcie mogą ubiegać się grupy producentów, a więc grupy, w skład których mogą wchodzić także przetwórcy uczestniczący w systemie jakości. Wsparcie w ramach tego poddziałania 
polega na refundacji $70 \%$ kosztów kwalifikowalnych poniesionych na przeprowadzenie działań informacyjno-promocyjnych.

Producenci ekologiczni mogą również skorzystać z działania „Tworzenie grup i organizacji producentów". Beneficjentami tego działania mogą być zarejestrowane grupy producentów lub organizacje producentów, które spełnią dodatkowe warunki kwalifikowalności określone w PROW 2014-2020. Wsparcie w ramach tego działania jest realizowane $\mathrm{w}$ formie rocznych płatności $\mathrm{w}$ okresie pierwszych pięciu lat od rejestracji grupy producentów lub powstania organizacji producentów. Wsparcie będzie stanowiło procentowy ryczałt od wartości przychodów netto beneficjenta ze sprzedaży produktów lub grup produktów, wytworzonych w gospodarstwach rolnych jego członków w poszczególnych latach i sprzedanych odbiorcom niebędącym jego członkami.

Kolejnym działaniem, które w istotnym stopniu może przyczynić się do rozwoju polskiego rolnictwa ekologicznego, jest działanie „Inwestycje w środki trwałe” w ramach poddziałań „Modernizacja gospodarstw rolnych” i „Przetwórstwo i marketing produktów rolnych". W ramach poddziałania „Modernizacja gospodarstw rolnych” przewidziane są preferencje dla rolnictwa ekologicznego. Tutaj stosuje się kryteria selekcji, które ukierunkowują pomoc na operacje dotyczące budowy lub modernizacji budynków inwentarskich oraz operacji, które wpłyną na zwiększenie uczestnictwa w rynku, zróżnicowanie produkcji rolnej lub dotyczą produkcji ekologicznej. Z powyższego wynika, że w ramach przeprowadzanych naborów operacje dotyczące m.in. produkcji ekologicznej będą dodatkowo premiowane spośród innych operacji spełniających kryteria kwalifikowalności i finansowane w pierwszej kolejności. W ramach poddziałania „Przetwórstwo i marketing produktów rolnych” kryteria wyboru będą uwzględniać m.in. operacje dotyczące wnioskodawców uczestniczących we wspólnotowych lub krajowych systemach jakości lub przetwarzających produkty rolne pochodzące bezpośrednio od producentów ekologicznych. W ramach poddziałania „Restrukturyzacja małych gospodarstw” pomoc jest przyznawana na restrukturyzację gospodarstwa w kierunku produkcji żywnościowych lub nieżywnościowych produktów rolnych, a także przygotowania do sprzedaży i sprzedaży bezpośredniej produktów rolnych wytwarzanych w gospodarstwie oraz przetwórstwa produktów rolnych pochodzących głównie z gospodarstwa. Za szczególnie istotne uznano, że mniejsze gospodarstwa (o wielkości ekonomicznej do 6 tys. euro), których posiadacze prowadzą produkcję ekologiczną lub zainteresowani są podjęciem takiej produkcji, będą objęci preferencjami w ramach tego poddziałania.

W ramach Programu Rozwoju Obszarów Wiejskich 2014-2020 realizowane jest wsparcie szkoleniowe w ramach działania "Transfer wiedzy i działalność informacyjna”. Realizacja tego działania ma umożliwić zarówno zwiększanie innowacyjności i bazy wiedzy na obszarach wiejskich oraz wzmacnianie powiązań między rolnictwem i leśnictwem a badaniami i innowacją, jak również promować uczenie się przez całe życie. W ramach poddziałania „Szkolenia zawodowe i nabywanie umiejętności” wsparcie będzie udzielane na szkolenia ukierunkowane na rozwój wiedzy i umiejętności zawodowych dotyczące zagadnień związanych w szczególności m.in. z technologią i organizacją produkcji w gospodarstwie, w tym produkcji ekologicznej. 
Nowym działaniem w PROW 2014-2020 jest działanie „Współpraca” - umożliwiające funkcjonowanie Europejskiego Partnerstwa Innowacyjnego na rzecz zrównoważonego i wydajnego rolnictwa (EPI). Wsparcie dotyczy form współpracy prowadzących do uzyskania nowych produktów, procesów, typów organizacji, w tym również nowych zakresów, tematów współpracy dla już istniejących grup podmiotów współpracujących przy realizacji nowych, wspólnych przedsięwzięć. Oczekiwanym efektem współpracy podmiotów powinny być nowe, innowacyjne rozwiązania praktycznych problemów zidentyfikowanych przez zainteresowane strony. $W$ ramach działania wspierane będzie tworzenie i funkcjonowanie partnerstw zrzeszających rolników (w tym grup producentów rolnych, spółdzielni rolniczych, jednostek naukowych, przedsiębiorców, posiadaczy lasów, organizacji pozarządowych, podmiotów doradczych), które w ramach grup operacyjnych na rzecz innowacji (EPI) będą wspólnie opracowywać nowe rozwiązania do zastosowania w praktyce.

Ponadto w ramach działania LEADER (poddziałanie „Realizacja operacji” w ramach „Lokalnych strategii rozwoju”) planuje się wspieranie operacji polegających na tworzeniu inkubatorów przetwórstwa lokalnego, rozwoju rynków zbytu oraz rozwoju produktów lokalnych. Przewiduje się również wspieranie różnych form współpracy w zakresie krótkich łańcuchów żywnościowych oraz zbytu produktów lokalnych. Rozwój rynku produktów ekologicznych będzie objęty pomocą pod warunkiem, że potrzeby w tym zakresie zostaną wskazane w lokalnej strategii rozwoju ${ }^{10}$.

\section{Podsumowanie}

Rynek produktów ekologicznych zarówno na świecie, jak i w Unii Europejskiej rozwija się dynamicznie. Wartość sprzedaży detalicznej w całej UE w 2015 r. wyniosła 27,1 mld euro, co oznacza wzrost w stosunku do roku poprzedniego o $12,7 \%$. Unijny rynek produktów ekologicznych, pod względem wartości sprzedaży detalicznej, uplasował się na drugiej pozycji w świecie po rynku północnoamerykańskim. Pod względem liczby gospodarstw ekologicznych Polska w 2015 r. zajęła szóstą pozycję w Unii Europejskiej. Rozwojowi rolnictwa ekologicznego w naszym kraju sprzyja niski stopień zanieczyszczenia środowiska, duże zasoby siły roboczej na wsi, a przede wszystkim rosnący popyt na produkty ekologiczne, będący wynikiem wzrostu świadomości konsumentów. Znaczący udział gruntów w trakcie konwersji na produkcję ekologiczną ${ }^{11}$ w Polsce prawdopodobnie będzie mieć wpływ na wzrost liczby producentów ekologicznych w najbliższych latach, a tym samym na zwiększenie podaży z produkcji krajowej.

\footnotetext{
${ }^{10}$ Ramowy plan działań dla żywności i rolnictwa ekologicznego w Polsce na lata 2014-2020, Ministerstwo Rolnictwa i Rozwoju Wsi, Warszawa 2014, s. 3-5 i 35-37.

${ }^{11}$ Okres konwersji oznacza czas przejścia z produkcji konwencjonalnej na produkcję ekologiczną, rozpoczyna się od momentu przystąpienia gospodarstwa do systemu kontroli i jest uzależniony od rodzaju produkcji (od 6 tygodni w przypadku drobiu nieśnego do 36 miesięcy w przypadku upraw wieloletnich, np. sadów i owoców jagodowych). Rozporządzenia Rady (WE) nr 834/2007 oraz Komisji (WE) $\mathrm{nr} 889 / 2008$.
} 
Wsparcie finansowe z PROW 2014-2020 będzie miało istotny wpływ na wzrost zainteresowania rolników produkcją metodami ekologicznymi. Najwięcej wniosków o dofinansowanie produkcji ekologicznej (stan na 30.09.2017) zostało zrealizowanych województwach zachodniopomorskim, warmińsko-mazurskim i podlaskim, co było skorelowane z największą liczbą gospodarstw ekologicznych na tych terenach.

\section{Literatura}

Brodzińska K.: Rolnictwo ekologiczne - tendencje i kierunki zmian, Zeszyty Naukowe SGGW. Problemy Rolnictwa Światowego 2014, t. 14, z. 3.

Europejskie partnerstwo innowacji: Możliwości dla innowacji w rolnictwie ekologicznym i agroekologii, Bruksela 2014 (dostęp: 29.04.2017).

EUROSTAT: Organic farming statistics (dostęp: 10.02.2017).

FiBL\&IFOAM: The World of Organic Agriculture, Frick and Bonn 2017.

Komorowska D.: Efektywność ekologicznych gospodarstw sadowniczych w porównaniu do konwencjonalnych, Zeszyty Naukowe SGGW. Ekonomika i Organizacja Gospodarki Żywnościowej 2016, 115.

Miś T., Zając D.: Problemy rozwoju rolnictwa ekologicznego w regionie o rozdrobnionej strukturze obszarowej, Zagadnienia Doradztwa Rolniczego 2017, 3.

Molenda-Grysa I.: Przesłanki produkcji żywności ekologicznej w Polsce - typologia potencjałów, Roczniki Naukowe Ekonomii Rolnictwa i Rozwoju Obszarów Wiejskich 2016, t. 103, z. 3.

Ramowy plan działań dla żywności i rolnictwa ekologicznego w Polsce na lata 2014-2020. Ministerstwo Rolnictwa i Rozwoju Wsi, Warszawa 2014.

Raport o stanie rolnictwa ekologicznego w Polsce w latach 2013-2014, IJHARS, Warszawa 2015.

Strefa Inspiracji Krajowego Ośrodka Wsparcia Rolnictwa. Moda na rolnictwo ekologiczne stała się faktem, www.kowr.gov.pl (dostęp: 20.11.2017).

Szarek S.: Regionalne zróżnicowanie rolnictwa ekologicznego w Polsce, Journal of Agribusiness and Rural Development 2015, 1(35).

\section{Organic farming in Poland and its development potential under the Rural Development Programme for 2014-2020}

Summary. The aim of the study was determination of the position of Polish organic farming comparing to organic farming in European Union, defining the regional locations of organic farming producers in Poland and identification of the financial support under the Rural Development Programme for 2014-2020. In the article the secondary data and the method of comparative analysis were used. Concerning the number of ecological farms, Poland had the sixth position in the European Union in 2015. The analysis shows that the largest number of applications for co-financing of organic production within framework for action "Organic farming" were implemented in the voivodeships with the largest number of organic farms in Poland: Zachodniopomorskie voivodeship, Warmińsko-mazurskie voivodeship and Podlaskie voivodeship.

Key words: organic farming, European Union, Rural Development Programme for 2014-2020 